\title{
Immune activation and MRgFUS
}

\author{
Katherine Ferrara*, Elizabeth Ingham, Andrew Wong, Azadeh Kheirolomoom, Brett Fite, Yu Liu, Lisa Mahakian,
} Sarah Tam

From Current and Future Applications of Focused Ultrasound 2014. 4th International Symposium

Washington, D.C, USA. 12-16 October 2014

\section{Background/introduction}

For many years, immune activation following tumor ablation has been evaluated in the treatment of systemic cancer. Ultrasound ablation is thought to promote dendritic cell maturation and T-cell immunity, and is particularly advantageous because it is non-invasive, can be controlled with high spatial precision and uses no harmful ionizing radiation.

\section{Methods}

Recently, immune adjuvants have been shown to be effective in treating metastatic cancer, with cancer immunotherapy named as the "breakthrough of the year" in 2013. At this time, combining ablation with immune adjuvants is a promising technique for expanding the utility of ultrasound for the treatment of systemic disease. We will briefly review the status of this combined therapy and opportunities for future studies.

Published: 30 June 2015

Submit your next manuscript to BioMed Central and take full advantage of:

- Convenient online submission

- Thorough peer review

- No space constraints or color figure charges

- Immediate publication on acceptance

- Inclusion in PubMed, CAS, Scopus and Google Scholar

- Research which is freely available for redistribution 